\title{
Primary familial polycythemia
}

INSERM

\section{Source}

INSERM. (1999). Orphanet: an online rare disease and orphan drug data base. Primary familial polycythemia. ORPHA:90042

Primary familial polycythemia is an inherited hematological disorder resulting from mutations in the erythropoietin (EPO) receptor and is characterized by an elevated absolute red blood cell mass caused by uncontrolled red blood cell production in the presence of low EPO levels. 